\title{
The Life of the Mind: A Study of Faculty Spaces in Academic Libraries
}

\section{Debra Engel and Karen Antell}

\begin{abstract}
The value of the academic library as "place" in the university community has recently been debated in the popular and scholarly library literature, but the debate centers on student use of library space rather than faculty use. This study addresses the issue of faculty use of library space by investigating the use of "faculty spaces"-individual, enclosed, lockable carrels or studies - through a series of interviews with faculty space holders at the University of Oklahoma and a survey of ARL libraries. Both elements of the investigation show that faculty spaces are heavily used and highly valued by faculty members, especially those in the social sciences and humanities. The researchers present the results of the interviews and the survey, and explore the reasons for the continuing value of faculty spaces in the age of electronic information.
\end{abstract}

"My blood will be on your hands if you ever take away my faculty study."

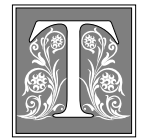

he value of the academic library as "place" in the university community has recently provoked debate in the popular and scholarly library literature. The increasing availability and popularity of library resources online supposedly renders the library building obsolete. Some observers even predict the demise of the library building as library resources increasingly deliver full-text content to desktops. ${ }^{2}$ Yet a growing body of literature reinforces the importance of the library as place. ${ }^{3}$ Most of this literature, however, addresses student use of library spaces rather than faculty use. This study endeavors to address this issue by examining one aspect of faculty use of academic library space.
The University of Oklahoma's Bizzell Memorial Library, the main library on campus, houses ninety-four faculty studies (private, lockable spaces containing a desk, a chair, a bookcase, and network connection). The popularity of these studies (they are always fully occupied, and there is often a waiting list to obtain one) is testament to the value of the library as place to faculty members. To investigate this phenomenon further, the researchers interviewed ten faculty members who use faculty studies located at Bizzell Memorial Library. These interviews took place during the 2002-2003 academic year. The researchers asked each faculty member to respond to a series of questions about the use of their library faculty study. In addition to conducting interviews, the researchers surveyed the 112 academic libraries that are members of the Associa-

Debra Engel is Director of Public Services in the University Libraries at the University of Oklahoma; email: dhengel@ou.edu. Karen Antell is the Engineering Librarian in the University Libraries at the University of Oklahoma; e-mail: kantell@ou.edu. 
The Life of the Mind 9

tion of Research Libraries (ARL) in November 2002, asking each institution about the availability and use of its faculty spaces as well as about the disciplines represented by faculty space holders and current guidelines governing the use of faculty spaces. Thus, this study examines not only how faculty space is utilized by faculty members at the sixty-three ARL libraries that responded to the survey, but it also considers what it is about the location of the faculty space within an academic library that is valued by individual faculty members. In other words, why is the faculty space highly valued "real estate" in the academic library?

Until now, the most recent systematic study of the use of faculty spaces in academic libraries was Peter Spyers-Duran's 1968 survey of thirty-two urban university libraries. ${ }^{4}$ This work is now thirtyfive years old, and because it predates the electronic revolution, it is particularly important to revisit this topic in light of the current debate on "deserted" libraries. In this paper, the results of the ARL survey portion of the present study will be compared to Spyers-Duran's 1968 results. However, it should be noted that the present survey is by no means identical to Spyers-Duran's. The Spyers-Duran survey focused on the administrative aspects of faculty spaces, whereas the present study takes a phenomenological approach in focusing on the nature of faculty members' use of faculty spaces. In addition, whereas Spyers-Duran surveyed 32 "relatively new ... urban" university libraries, the present study surveys 112 ARL member libraries that are not necessarily new or urban. In addition, Spyers-Duran does not indicate whether the libraries surveyed belonged to institutions focused on research or teaching. It is possible that the results of the current survey of ARL libraries are not applicable to libraries at teaching-focused universities.

The terms "faculty carrel" and "faculty study" are both used frequently to refer to enclosed, individual spaces for faculty use. The difference between the carrel and the study is usually a matter of size, but both include at the very least a desk, a chair, and a place for books. To eliminate ambiguity, the present discussion will use the more general term "faculty space" to describe any enclosed, lockable, individual space used by faculty members, whether or not it meets the definition of a carrel or a study. Open faculty carrels with lockable storage compartments are not included.

\section{Literature Review}

In a provocative article titled "The Deserted Library," Scott Carlson discusses decreased gate counts and circulation rates in academic libraries, attributing this evidence of the "deserted library" to an increase in the number of Web-based resources and a corresponding increase in student use of alternative spaces such as dorm rooms, coffee shops, and bookstores. ${ }^{5}$ His article has sparked intense discussion among academic librarians about the role of the library within the campus community. Carlson reports that fewer students are actively using library resources within the physical library facilities. Shortly after the 2001 appearance of "The Deserted Library," Mary Reichel and Deanna B. Marcum moderated an online follow-up dialogue in which many participants challenged Carlson's claims, asserting that the "college library is not seeing a decrease in use of the library building on campus." ${ }^{\prime}$ Although germane to the debate about the use of library space in the electronic age, both Carlson's article and the transcript of the follow-up dialogue focus almost exclusively on student use of library space rather than faculty use.

Earlier examinations of the use of library space also emphasize use by students, not faculty members. For instance, in a 1971 study of carrels in academic libraries, William J. Quinly advocated the adoption of the student carrel as the ideal type of student study space, noting that "most learners prefer to study alone, in the midst of their fellow learners, surrounded by the total resources of the li- 


\section{College \& Research Libraries}

brary." ${ }^{7}$ Moreover, in the 1970s and 1980s, trends in academic library construction included a shift from planning space for physical materials to planning space for users and user activities, such as learning centers and information utilityagain, space uses that focus on student use and student needs. ${ }^{8}$ Research on faculty use of academic library space per se simply does not exist; the literature on faculty use of academic library space focuses exclusively on information-seeking behaviors or the use of specific resources.

The only research to focus exclusively on faculty spaces, as noted previously, is Spyers-Duran's 1968 survey. His purpose was to "review the current trend of faculty use of library studies as well as probe selected institutional policies, problems, and attitudes." ${ }^{9}$ His conclusions offer guidelines for library administrators in the management of faculty spaces, but he does not address faculty members' perceptions of the value of faculty spaces. In other words, his study focuses exclusively on the library administrator's perspective on faculty spaces and does not consider the faculty member's perspective.

Many recent articles explore the concept of "library as place" and illustrate how the use of library space has changed in the past two decades with the advent of electronic resources. In several articles on the topic, Walt Crawford consistently asserts that libraries as physical facilities will continue to thrive. As recently as the April 2003 issue of American Libraries, Crawford reinforces the idea that "in addition to collections, libraries provide a place for people to meet, study, read, research, play, and find answers to their questions," reiterating the theme that library buildings provide space for people and their activities, not just for materials storage. ${ }^{10}$ Crawford also comments on the use of libraries as study spaces, noting that "[v]ery few libraries can serve their users well without setting aside space for study. There's a natural connection between libraries and study."11 Deborah Holmes-Wong and colleagues elaborated on this theme, indicating that library
January 2004

buildings have moved beyond their original mission of providing space for resources to providing learning environments for the purpose of creating new knowledge and providing enhanced space for optimal library instruction. ${ }^{12}$

The importance of the library building as the intellectual center of the academic community has been well illustrated. Historian Shelby Foote expresses a common sentiment: "[a] university is just a group of buildings gathered around a library."13 Holmes-Wong and colleagues asserted that the "library is the focal point of the university's intellectual life." 14 But the advent of vast electronic resources has fuelled the debate about the need for physical library space. Michael Gorman, although not an adherent of the "deserted library" camp, has reflected its sentiments in remarking that "[a]s technology has enabled some library service to be available away from the place called the library, it has made that place less important in some people's minds." ${ }^{15}$ William Gosling has noted the fact "[ $t$ ]hat the library still thrives as place is also evidenced by the number of enlarged or new library buildings being constructed."16 John N. Berry applauded the building of a new academic library that combined the advantages of the virtual library with the tangible vigor of a physical building designed to accommodate a variety of uses for collections, people, and access points. ${ }^{17}$

In the early 1990s, Michael Gorman commented, "The library is important because it satisfies users' desire to browse [and] because it is of symbolic importance to many scholars (why is it that an office in the library is one of the most prized of academic plums?) ${ }^{\prime 18}$ Crawford reiterates this idea by suggesting that "the next great library debate may be over space." ${ }^{\prime 19}$

Complementing the literature from the United States, a May 2000 survey of thirtyeight current academic library buildings and their activities in Australia reveals several common views about the "continuing need for physical space" in the academic library of the future, including the need for self-service facilities, a sup- 
portive physical environment, and access to print and electronic resources. ${ }^{20}$ The functional aspects of the library building and, in Larry Dowler's words, the "power of place" suggest strongly that the library's physical facility is essential to its mission: "[n]ext to a 'room of one's own,' we often find such places in a library, and we come to regard such places as our own." 21 This study suggests that, for university faculty members, individual faculty spaces are precisely this kind of essential space.

\section{Methodology}

This study combines two methodologies: interviews of faculty space users at the University of Oklahoma and a survey of ARL member libraries. The interviews generated qualitative data about individual faculty members' reasons for using faculty spaces. The ARL survey, on the other hand, supplied quantitative data regarding the characteristics of faculty spaces and their users at research libraries, including availability, occupancy rate, demand, furnishings, services, usage policies, and users' gender and departmental affiliation.

For the interviews, the researchers selected ten faculty space occupants who are generally representative of the ninetyfour faculty space users at the University of Oklahoma. The factors considered in selecting interviewees include gender, departmental affiliation, rank, and length of occupancy in the faculty space. For example, because 70 percent of the ninetyfour faculty space holders are male and 30 percent are female, the selection for the interviews included seven men and three women. Likewise, the selection of interviewees by discipline, academic rank, and length of occupancy in the faculty space roughly corresponds to the breakdown by discipline, academic rank, and length of occupancy of all ninety-four faculty space holders. Although the interview sample of ten is not large enough to allow the researchers to draw statistically valid inferences, it is sufficient to provide significant qualitative data regarding fac- ulty members' reasons for using faculty spaces. As such, the interviews complement the ARL survey by providing data that the survey could not possibly generate.

Phenomenological research, as this type of study is sometimes called, generates data that are limited to a small number of subjects but provide an in-depth understanding of a particular phenomenon-in this case, the phenomenon of the popularity of faculty spaces. By the same token, the ARL survey complements the interviews by providing a broader and statistically valid context for interpreting the interviews in light of the "deserted libraries" debate. Together, these two methodologies supplied a powerful combination of qualitative and quantitative data about the use of faculty spaces in academic libraries.

\section{Interview Methodology and Results}

Ten University of Oklahoma faculty members representing a variety of disciplines were interviewed about the use of their faculty spaces at Bizzell Memorial Library, the main library on campus, which houses ninety-four faculty spaces on five floors of the library building. In the interviews, faculty members were asked fourteen questions (appendix A) about the use and value of their faculty spaces to their research and teaching. The disciplines represented by the ten faculty members include English, history, political science, physics, honors, psychology, philosophy, and library science. Three women and seven men were interviewed; their ranks included assistant professor, associate professor, and full professor. Five interviewees have used their faculty spaces for more than ten years, and one has held his faculty space for thirty-five years. Three have held their faculty spaces for less than five years.

The interviews reveal that faculty members typically use their faculty spaces on a consistent basis, scheduling time there as part of their regular workweek. Most faculty members report that they plan for at least a half-day's work in their 


\section{College \& Research Libraries}

faculty spaces two to five times a week. One faculty member maintains that he spends almost all of his working time in his faculty space. Several participants elaborate on the reasons for their consistent patterns of use with remarks such as "I can count on getting work done there. I know I will be able to put in three or four good hours and finish whatever it is I need to get done." In addition, eight participants use their faculty spaces only for research activities. Teaching responsibilities typically are relegated to departmental offices, not faculty spaces.

The specific activities that faculty members reported doing most frequently in their faculty spaces are research-related reading, thinking, and writing. While in the library, they also browse the stacks and use the library coffee shop. On the other hand, most participants say that they avoid certain activities while in their faculty spaces, activities that break their concentration on research such as checking e-mail and meeting with students and colleagues.

Several themes emerged from the interviews with faculty about their use of faculty spaces, including:

- The faculty space is an oasis of solitude, a place for sustained, uninterrupted thinking or reading, and a quiet place for reflection.

- The faculty space's location within the library enables "serendipitous browsing," which is valuable to faculty members' work.

- Faculty members' "academic upbringing" has habituated them to using the library as the primary place for doing research. Going to the library is a ritual that puts them in the right frame of mind to do serious work.

These themes are examined in more detail below.

\section{Oasis of Solitude}

All ten interviewees expressed the idea that the faculty space represents an oasis of solitude where they can focus their concentration and accomplish high-quality work without interruption. For some,
January 2004

the study is a sanctuary for writing: "The best five paragraphs of my book were written in my faculty study." For others, the study is an ideal place to "take a stack of articles and get up to speed on a topic" or "to sort interlibrary loan materials I had requested without interruption." Faculty members explicitly stated that they choose to work in their faculty spaces rather than in their departmental offices when they want to work without distractions or interruptions by colleagues or students. One faculty member suggested that her faculty space is particularly useful not only because it is quiet, but also because it provides "a freedom of focus without distraction." Another referred to it as "sacred space." A faculty member who described his faculty space as being "intellectually freeing" reported that the quality of the work he accomplishes within his faculty space is of a higher quality than the work he is able to accomplish in his departmental office.

Neither telephones nor telephone lines are provided in the faculty spaces at Bizzell Memorial Library. In these days of ubiquitous cell phones and de rigueur instant accessibility, it is striking that not one interviewee wanted a telephone in his or her faculty space. Perhaps more than any other indicator, the desire to escape from telephone contact reveals the faculty spaces' importance as oases of solitude. Some faculty members choose to take cell phones to their faculty spaces, but most report that they rarely take calls there.

The importance of solitude is reinforced by the location of the faculty spaces in the library, away from the faculty members' departmental offices. Seclusion from interruption also may elicit a state of mind conducive to analytical thinking, research, and writing. "I've always done my best work in quiet libraries," said one interviewee.

\section{Serendipitous Browsing}

Part of the faculty space's value to researchers lies in its proximity to the collections of monographs and print journals. The importance of serendipitous 
browsing in the library collections cannot be overemphasized by the majority of faculty space holders. "It's that one minute out of fifty-nine [minutes], when you find that one gem on the shelf" that makes the act of browsing not only effective but absolutely vital to many researchers. As one participant emphatically noted, "There is no substitute for walking the stacks. It's not 'browsing' — that sounds too aimless. It is more directed'surveillance,' really." On a related note, one faculty member expressed the concern that today's students have lost the art of browsing: They do a quick catalog search, retrieve the books they want, and leave, missing a wealth of valuable and relevant materials that are not so much "retrieved" as "discovered."

During the interviews, the theme of serendipitous browsing emerged repeatedly with regard to research, but it has some applicability to teaching as well. For the two interviewees who use their faculty spaces for teaching activities, the faculty spaces' proximity to library collections was noted as an asset that enhances their teaching by making it easier to browse for materials suitable for their courses.

Two long-time occupants of faculty spaces noted that they had specifically requested a faculty space located near the collections in their subject area. One participant who had only recently obtained a faculty space noted that, although it would be useful to have a faculty space located close to her subject area, she was glad to take the first faculty space that was offered to her.

\section{“Academic Upbringing”}

Several faculty members felt that the desire to have a faculty space in the library is a natural progression of their "academic upbringing": They learned to do scholarly work in the library, and many used graduate student carrels while working on their master's or Ph.D. programs. One participant said that the availability of the faculty space was one of the factors he considered when interviewing for his position with the university, and he felt that his productivity was strongly and positively influenced by the availability of a faculty space early in his career. Another faculty member said that his academic upbringing, starting when he was an undergraduate, inculcated in him the principle that "you go to the library to study," and he believes this notion was influential in his decision to request a faculty space. Along the same lines, several participants believed that if they did not have access to a faculty space, their research would suffer and they would be forced to do their research at home, which they perceived as a poor substitute for working in their faculty spaces.

\section{Survey Methodology and Results}

The survey (appendices B and C) was sent to academic libraries that are ARL members. The sample size was 112 . Of these, sixty-three returned the survey, for a response rate of 56 percent. The survey requested information about faculty spaces in main libraries only, not subject-specific branch libraries.

Forty-seven of the sixty-three respondents, or 75 percent, reported that their libraries housed individual faculty spaces of some sort. Spyers-Duran's 1968 study, the only comparable survey on the topic, reported that 65 percent of libraries surveyed housed individual faculty spaces. ${ }^{22}$ In the present survey, respondents were asked to characterize their libraries' faculty spaces as carrels or studies using the following guidelines: "[a] carrel is usually considered to be a small lockable space with just enough room for a desk, attached shelf, and chair. A study is somewhat larger and may have room for additional furnishings." ${ }^{23}$ Seventeen of the forty-seven respondents (36\%) indicated that their faculty spaces were studies, and thirty respondents $(64 \%)$ indicated that their faculty spaces were carrels.

In the present study, the institutions that reported housing faculty spaces have, on average, 20,642 undergraduate students, 5,771 graduate students, and 2,002 faculty members. The average number of 
14 College \& Research Libraries

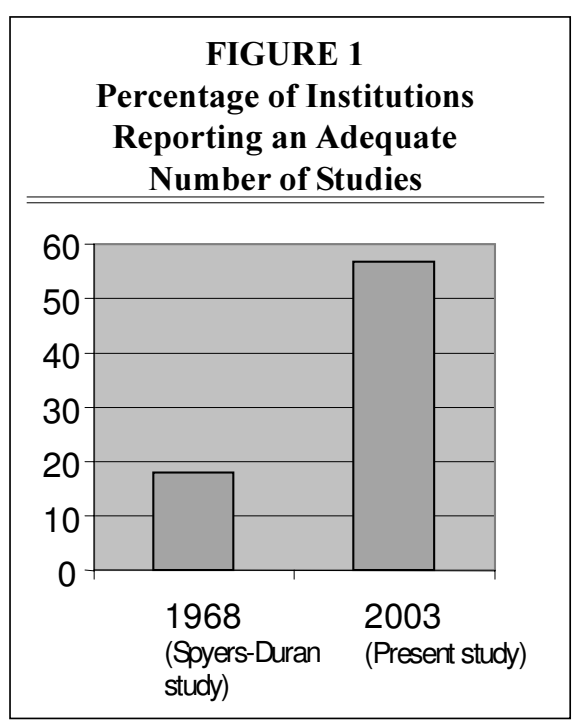

faculty spaces at each institution is 122 , but this figure ranges widely, from a low of three to a high of 680 . On average, men occupy 67 percent of the faculty spaces and women occupy 33 percent. This is similar to the gender division among academics generally: Recent figures indicate that men account for 64 percent of faculty members at four-year colleges and universities, and women account for 36 percent. ${ }^{24}$

The disciplines represented by faculty space occupants overwhelmingly come from the humanities and social sciences. At 87 percent of institutions, the humanities or social sciences are the top-ranking disciplines represented by faculty space occupants. All of the respondents, not surprisingly, indicated that their institution's faculty spaces contain desks and chairs, and bookcases were reported by 93 percent of respondents. Other furnishings are much rarer: Only 16 percent of institutions provide filing cabinets, and only one institution (2.3\% of the sample) provides an easy chair. No institution provides a computer, and only five percent provide telephones. Fifty-six percent of respondents indicate that their faculty spaces are equipped with network connections, even though only nine percent report telephone lines. Perhaps this is not surprising, given
January 2004

the "oasis of solitude" theme expressed in the interviews: For many occupants, the faculty space is a place for uninterrupted work, not a place for telephone conversations. Although the survey did not ask specifically about wireless network connections, three institutions indicated in the "other" category that they provide this service, and several others noted that wireless connections are planned. This is not surprising because the installation of wireless connectivity in academic libraries is a known trend. Roy Tennant has noted that "the early adopters [of wireless networks in libraries] are largely academic libraries." ${ }^{25}$ Firm figures are not available, but in an informal poll, 246 academic libraries in the United States reported that they offered wireless connectivity as of September $3,2003 .^{26}$

In the present study, respondents were asked whether the number of faculty spaces was adequate for the number of faculty at the institution. Three respondents did not answer this question. Of the forty-four responses, twenty-five (57\%) indicated that the number of faculty spaces is adequate; the remaining nineteen $(43 \%)$ indicated that the number of faculty spaces is inadequate. This finding provides a sharp contrast to SpyersDuran's findings on the same topic. In the 1968 study, only 18 percent of respondents reported an adequate number of faculty studies, and 82 percent reported an inadequate number. ${ }^{27}$ (See figure 1.)

The present study and the 1968 study show some similarities in the ratios of the number of faculty to the number of available study spaces. This ratio was obtained by dividing the number of faculty members employed at the institution by the number of faculty spaces available. In the present study, the average faculty-to-space ratio among all respondents is 58.1; that is, on average, responding institutions have one faculty space available for every 58.1 faculty members. In the 1968 study, this ratio was 42.3. In both surveys, not surprisingly, the average faculty-to-space ratio is lower for institutions reporting an adequate number of studies: 38.7 in the present study, and 
16.1 in the 1968 study. The average facultyto-space ratio for institutions reporting an inadequate number of studies was higher: 87.3 in the present study, and 52.8 in the 1968 study. It appears that, in 2003, fewer faculty spaces are required for a library to achieve an "adequate" rating than in 1968. (See figure 2.)

One gauge of the demand for faculty spaces is the existence of a waiting list for faculty space. The 1968 survey did not address this issue, but the present study revealed that twenty-two institutions $(48 \%)$ have a waiting list for faculty spaces. Of those, the average number of names on the waiting list is 16.3. Among institutions reporting an adequate number of studies, however, the average waiting list has only 2.6 names. Institutions reporting an inadequate number of studies, on the other hand, have an average waiting list of 17.4. (See figure 3.)
Forty-four of the forty-seven respondents in the present study answered the question about the existence of a written policy governing the use of faculty spaces. Of these, forty (91\%) indicated that their institution has such a policy, whereas only four $(9 \%)$ reported having no written policy. In 1968, only 50 percent of respondents reported having a written policy on faculty studies. Spyers-Duran suggested that the lack of a written policy might contribute to the faculty study "problem," namely, faculty members' failure to observe regulations regarding food, drink, typewriter noise, smoking, and other housekeeping issues. ${ }^{28}$

\section{Discussion: Passion and Apprehension}

When initially contacted by the researchers to discuss their use of their faculty spaces, several faculty members expressed

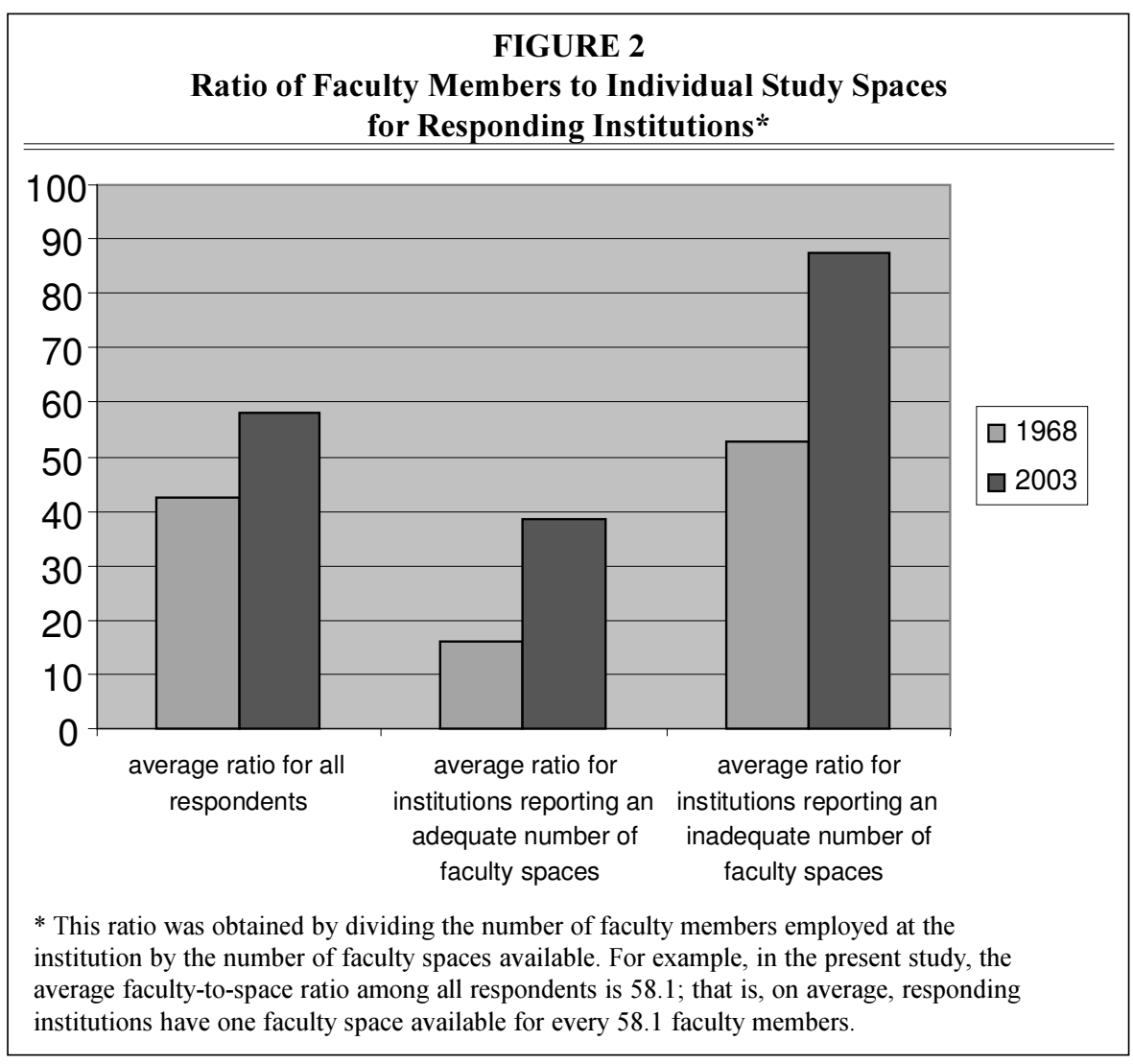




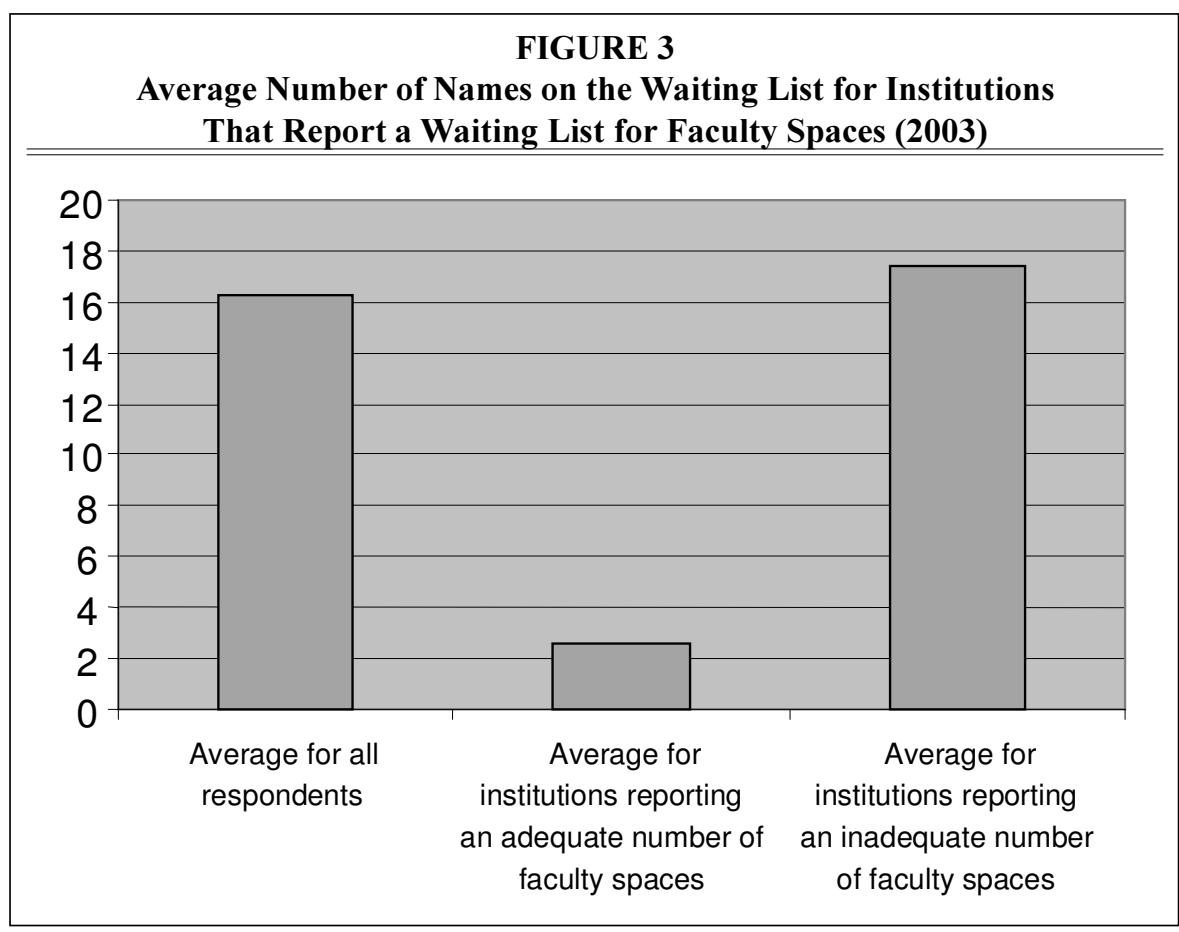

concern that perhaps the faculty spaces were being reallocated to meet other space needs in the library. However, after being reassured either in person or by telephone that they were not being asked to evacuate their faculty spaces, faculty members were uniformly delighted to participate. At the beginning of each interview, the researchers assured the participant that the interviews' purpose was to shed light on the nature of the faculty spaces' use and their value to faculty members. Participants seemed to enjoy the chance to talk about their spaces' value, and several of them noted that no one had ever asked them about their faculty spaces before.

Although the researchers expected to learn about the faculty members' reasons for valuing their faculty spaces, they did not anticipate the amount of passion faculty members expressed in these discussions. The passion was matched in part by an element of apprehension and even sorrow elicited by one of the questions asked in the interviews: "If you took a position at a university that did not offer faculty studies, how would your work habits change?" (See appendix A.) When discussing the possibility of losing their faculty spaces, interviewees expressed a significant sense of loss. Many had obviously thought about how they used their study and what it meant to them over a long period of time.

This passion, and the concomitant apprehension, seem directly related to the expressed importance of faculty spaces in faculty members' research activities. Although the ARL library survey does not reflect the passion conveyed by the interviewees, the survey data do lend credence to several of the use patterns that emerged in the interviews. For instance, as noted earlier, eight of the ten interviewees reported emphatically that they use their faculty spaces for research purposes only, never for teaching preparation or meeting with students. The ARL survey data indirectly support this use pattern. Thirty-one institutions submitted copies of their faculty space policies with their surveys, and of these, twenty-four (77\%) explicitly stated that faculty spaces are to be used for research purposes only, 
The Life of the Mind 17

not for meeting with students. The SpyersDuran study expressed a similar finding: "none of the libraries [surveyed] permit the use of studies as office space. This may be one of the reasons no faculty study is equipped with a telephone. The lack of telephones is also a feature preferred by researchers." 29 This notion also rings true today. One interviewee reflected the sentiments of many when he noted, "[my faculty space] is a sacred space for research." In fact, one of the signature characteristics of faculty space holders is their unequivocal desire for solitude and uninterrupted time for research and writing: "It's the only place where I can work with any sense of peace and quiet." With only nine percent of respondents from the present survey of ARL libraries reporting that their faculty spaces are equipped with telephone lines (and only $4 \%$ reporting that they provide telephones), insulation from unwanted telephone interruptions clearly remains almost as important to faculty members today as it was in 1968, when SpyersDuran reported that none of the respondents provided telephones.

The absence of telephones is not the only way in which libraries protect the sanctity of the faculty space. Several of the faculty space policies submitted by ARL libraries explicitly stated that staff members may not disclose information about the location of a particular professor's faculty space or page professors from their faculty spaces. This is also the case at the University of Oklahoma, although it is not included in the written policy on faculty spaces. Anecdotally, the researchers have noticed at several academic libraries that faculty space holders quarantine themselves from unwanted human contact by lining the windows of their spaces with paper or posters, presumably to thwart would-be drop-in visitors. The SpyersDuran study reflected this emphasis on privacy: "[s]ixty percent of libraries will not 'page' a faculty member out of respect for his [sic] sanctuary and for other practical reasons." ${ }^{30}$ As Walt Crawford noted in Being Analog, "The life of the mind sometimes requires peace and quiet." ${ }^{31}$
Interviewees also strongly opposed the notion that all the information they need is available electronically; faculty space occupants are self-avowed heavy users of print journals and monographs. The survey findings indirectly supported this result as well: In addition to the statistics from the ninety-four faculty spaces at Bizzell Memorial Library, ${ }^{32}$ the survey results indicated a majority of faculty space occupants from the disciplines of the humanities and social sciences, fields that are well known to be the heaviest users of print among all the academic disciplines. ${ }^{33}$

Faculty spaces are a unique real estate asset in the academic library. The interviewees' passion about their faculty spaces indicates that the spaces' value to their research efforts is immeasurable. From the perspective of these faculty members, no other space on campus can compare in merit as a place to do scholarly work.

\section{Conclusion}

The demise of the academic library as place in the age of electronic information, that is, the "deserted library," has been discussed vigorously in recent library literature, but almost all of the debate centers on student use of library space rather than faculty use. This study was undertaken to shed more light on faculty use of library space. It focuses, in particular, on faculty spaces-individual, lockable carrels or studies. Although the use of faculty spaces does not necessarily represent faculty use of the library building as a whole, it is one gauge of faculty use of library space. Furthermore, it has the virtue of being more precisely quantifiable than measurements such as gate counts.

Both elements of this study-the survey of ARL libraries and the interviews with faculty space holders-demonstrate that faculty members have not deserted faculty spaces in academic libraries. The interviews reveal that faculty spaces at the University of Oklahoma are not only used heavily but also are valued highly by their occupants. The survey shows that this pattern is not unusual: More than 70 per- 


\section{College \& Research Libraries}

cent of ARL respondents indicated that their faculty spaces were fully occupied, and almost half reported the existence of a waiting list for faculty space, one with as many as fifty-seven names on it. This kind of demand undermines the notion of the "deserted library," at least with regard to faculty spaces. Although faculty spaces are no longer as scarce a commodity as they were in 1968, when only 18 percent of Spyers-Duran's respondents reported having an adequate number of faculty spaces, they are far from being superfluous. Today, 43 percent of ARL respondents report that they do not have enough faculty spaces. Anecdotally, the researchers find it striking that, although the University of Oklahoma Libraries engages in no publicity efforts on behalf of its ninety-four faculty spaces, the spaces remain fully occupied, usually with five or more faculty members on the waiting list.

Given the overwhelming revolution in the availability of electronic information between 1968 and the present, it is also striking that so many faculty members still demand space in the library and value this territory so passionately. After all, in 1968, the library building was the main provider of most types of academic information. In 2003, this is hardly the case. Electronic databases enable many kinds of research from any Internet-connected computer, yet faculty space holders remain firmly grounded in the library building; indeed, most of them claim that the library building is the principal place where they conduct their academic work.

However, one of the themes arising from the faculty interviews raises a provocative question. Several faculty members indicated that they prefer to work in the library building because of their "academic upbringing." As one interviewee noted, "Possibly it's generational-for my generation, you go to the library to do scholarly work." If one reason for faculty members' preference for working in the library building is habit or ritual, the following question naturally arises: Will future generations of academics, coming of
January 2004

scholarly age in the era of electronic information, continue to view the library building as the primary place for doing research? Although this question was not part of the interviews, several interviewees addressed it directly or indirectly in comments that registered nostalgia for the academic work ethic that stressed the traditional research use of monographs and print materials:

- "Electronic access to journals is great, but I wish students could be introduced to the library in the charming way that I was."

- "Intellectual inquiry is hard. It takes time and reflection. Students think writing a term paper is easy and quick. They aren't sitting down to do work."

- "Students today are going into the literature with a laser-like bandwidth, but they are not bending their minds around the larger, broader issues brought to them by books and by serendipitous browsing. There's been a spate of academic misconduct caused by this, because they are technicians, not scholars."

In the age of electronic information, library facilities and library resources are no longer entwined. The recent discussion of "deserted" libraries begs the question, what is the value of the library as place apart from its resources? This study shows that, at least for faculty members who use faculty spaces, the academic library facility in itself retains value as a place for "the life of the mind"-quiet reflection, sustained concentration, productive research effort, and high-quality writing. But this value stems partly from faculty members' "academic upbringing" during a time when library facilities and resources were integrated. In the future, then, research on faculty informationseeking behaviors, which now focuses almost exclusively on the use of resources, will need to address how the emerging generation of academics uses and values library facilities. If the academic upbringing of younger faculty members does not include the practice of using the resources and space in a library, will faculty spaces soon sit vacant? 


\section{Notes}

1. David W. Levy, University of Oklahoma David Ross Boyd Professor of History, interviewed by authors, Norman, Okla., July 2, 2002. A35.

2. Scott Carlson, "The Deserted Library," Chronicle of Higher Education 48 (Nov. 16, 2001):

3. Paul Evan Peters, "Is the Library a 'Place' in the Age of Networks?" Educom Review 29 (Jan./Feb. 1994): 62-63; Rod Henshaw, "Guest Editorial: The Library as Place," College and Research Libraries 55 (July 1994): 283-85; Walt Crawford and Michael Gorman, Future Libraries: Dreams, Madness and Reality (Chicago: ALA, 1995); Charlene Hurt, "Building Libraries in a Virtual Age," CERL News 58 (Feb. 1997): 75-76, 91; Walt Crawford, "Library Space: The Next Frontier," Online 23 (Mar./ Apr. 1999): 61-66; Alice Harrison-Bahr, “Library Buildings in a Digital Age: Why Bother?" CERL News 61 (July / Aug. 2000): 590-91, 608; Sam Demas and Jeffrey A. Scherer, "Esprit de Place: Maintaining and Designing Library Buildings to Provide Transcendent Spaces," American Libraries 33 (Apr. 2002): 65-68.

4. Peter Spyers-Duran, "Faculty Studies: A Survey of Their Use in Selected Libraries," College and Research Libraries 29 (Jan. 1968): 55-61.

5. Carlson, "The Deserted Library"

6. Scott Carlson (moderator) with Mary Reichel and Deanna B. Marcum, "Are College Libraries Too Empty?" Live Colloquy: Deserted Libraries [transcript of online discussion], Nov. 15, 2001, 2:00 pm (EST). Available online from http://chronicle.com/colloquylive/2001/11/empty/. (Accessed 23 May 2003.)

7. William J. Quinly, “Carrels for Learning,” Library Trends 19 (Apr. 1971): 468-69.

8. Nancy R. McAdams, “Trends in Academic Library Facilities," Library Trends 36 (fall 1987): 287-98.

9. Spyers-Duran, "Faculty Studies," 55.

10. Walt Crawford, "The Crawford Files: Libraries, E-books, and Monolithic Solutions," American Libraries 34 (Apr. 2003): 88.

11. Crawford, "Library Space," 62.

12. Deborah Holmes-Wong, Marianne Afifi, Shahla Bahavar, and Xioyang Liu, "If You Build It, They Will Come: Spaces, Values, and Services in the Digital Age," Library Administration and Management 11 (spring 1997): 74-85.

13. International Federation of Library Associations and Institutions, "Quotations about Libraries and Librarians." Available online from http://www.ifla.org/I/humour/subj.htm. (Accessed 20 May 2003.)

14. Holmes-Wong, Afifi, Bahavar, and Liu, "If You Build It, They Will Come," 74.

15. Michael Gorman, Our Enduring Values: Librarianship in the 21 $1^{\text {st }}$ Century (Chicago: ALA, 2000), 43.

16. William Gosling, "To Go or Not to Go? Library as Place," American Libraries 31 (Dec. 2000): 45.

17. John N. Berry, "The Cult of the Virtual Library," Library Journal 123 (Oct. 1, 1998): 6.

18. Gorman "The Academic Library in the Year 2001: Dream or Nightmare or Something in Between? Paper given to the Michigan Academic Library Forum, Ann Arbor, May 1990." Journal of Academic Librarianship 17 (Mar. 1991): 5.

19. Crawford, "Library Space," 61.

20. Helen King, "The Academic Library in the $21^{\text {st }}$ Century-What Need for a Physical Place?" Virtual Libraries: Virtual Communities: 21st IATUL Conference, Queensland University of Technology Library, Brisbane, Queensland, Australia, 3rd -7th July 2000. Available online from http:/ / educate.lib.chalmers.se/IATUL/proceedcontents/qutpap/king_full.html. (Accessed 20 May 2003.)

21. Larry Dowler, "Our Edifice at the Precipice," Library Journal 121 (Feb. 15, 1996): 118-20.

22. Spyers-Duran, "Faculty Studies," 56.

23. Based on descriptions from Philip D. Leighton and David C. Weber, Planning Academic and Research Library Buildings, 3rd ed. (Chicago: ALA, 2000), 233-34.

24. National Center for Education Statistics, Office of Educational Research and Improvement, U.S. Department of Education, "Gender and Racial/Ethnic Differences in Salary and Other Characteristics of Post-Secondary Faculty: Fall 1998." Published September 2002. Available from http:/ / nces.ed.gov/pubs2002/2002170.pdf. (Accessed 21 May 2003.)

25. Roy Tennant, "Free as a Bird: Wireless Networking," Library Journal 127 (Aug. 15, 2002): 32.

26. Bill Drew, "Libraries with Wireless Networks," Wireless Librarian Web site. Available from http:/ / people.morrisville.edu/ drewwe/wireless/wirelesslibraries.htm. (Accessed 16 September 2003.)

27. Spyers-Duran, "Faculty Studies," 56. 


\section{College \& Research Libraries}

28. Ibid., $57-58$.

29. Ibid.

30. Ibid.

31. Crawford, Being Analog: Creating Tomorrow's Libraries (Chicago: ALA, 1999), 62.

32. At Bizzell Memorial Library, sixty-three of the ninety-four faculty space holders $(67 \%)$ come from the disciplines of the humanities and the social sciences.

33. See, for example, Amy Friedlander, Dimensions and Use of the Scholarly Information Environment (Washington, D.C.: Council on Library and Information Resources, 2002). Available online from www.clir.org/pubs/reports/pub110/introduction.html. (Accessed 20 May 2003.) 
The Life of the Mind 21

\section{APPENDIX A Questions Asked in Interviews with Faculty Space Occupants}

1. Why did you get a faculty study in the library?

2. What kinds of work do you prefer to do in your study? What kinds of work do you prefer to do in your department? In other words, when you have work to do, what helps you decide whether to work in your study or in your department?

3. One faculty member has characterized the use of the faculty study in the following manner: "I can accomplish higher-level thinking in my faculty study. In my departmental office, I handle interruptions, students, faculty meetings, etc." Do you agree or disagree with this statement, and why?

4. How has your use of your study changed over time?

5. When you go to your study, do you tell your department where to find you? Do you hold office hours in your faculty study?

6. If you took a position at a university that did not offer faculty studies, how would your work habits change?

7. Have you ever been at another university where faculty studies were available? Did you have one? If so, were there any differences between that university's studies and OU's?

8. What do you like least about your faculty study?

9. What do you like most about your faculty study?

10. What would you like to change about your faculty study?

11. Why is your faculty study of value to you?

12. Is there anything that you would like to change about Bizzell Memorial Library or the branch libraries? (Prioritize three areas.)

13. Do graduate students and undergraduate students use the library more or less than five years ago? Ten years ago?

14. In your opinion, what is the future of the library building in the electronic information age? 


\section{APPENDIX B}

\section{ARL Academic Library Survey}

Name of your institution:

1. Does your library provide individual lockable studies or carrels to faculty members? (If no, skip remaining questions.) $\square$ yes $\square$ no

2. How many FTE faculty members does your institution employ?

3. How many FTE undergraduates does your institution enroll?

4. How many FTE graduate students does your institution enroll?

5. How many studies or carrels do you have

6. Would you characterize your library's individual faculty space as a study or a carrel? $\square$ study $\square$ carrel

(A carrel is usually considered to be a small lockable space with just enough room for a desk, attached shelf, and chair. A study is somewhat larger and may have room for additional furnishings.)

7. Are retired faculty members eligible for studies or carrels? $\square$ yes $\square$ no

8. Are your studies or carrels fully occupied? $\square$ yes $\square$ no

9. Is there a waiting list for studies or carrels? $\square$ yes $\square$ no

10. If so, how many people are typically on the waiting list?

11. Is the number of studies or carrels adequate for the number of faculty at your institution? $\square$ yes $\square$ no

12. Can faculty check out books and materials to the study or carrel? $\square$ yes $\square$ no

(This is not the same as checking out books to him- or herself and leaving them in the carrel. If books are checked out to a carrel, library staff know where they are and can access them if another patron needs them.)

13. Please rank the top three disciplines that are represented by your study or carrel holders (indicate using " 1 ," " 2 ," and " 3 ").

Humanities (English, philosophy, languages, classics, etc.)

Social Sciences (history, psychology, sociology, political science)

Fine Arts

Sciences

Engineering

Business

Education

Health Sciences

Professional Schools (social work, library science, law, journalism, etc.)

Other (please specify)

14. Can you provide an approximate breakdown of the studies' or carrels' occupancy by gender? $\%$ Women $\%$ Men

15. Is there a written policy that governs the use of the studies or carrels? $\square$ yes $\square$ no

16. If so, could you send us a copy of it? (If yes, please attach.) $\square$ yes $\square$ no 
The Life of the Mind 23

17. Is there a limit on how long a faculty member can keep a carrel or study? $\square$ yes $\square$ no 18. If so, what is the limit?

19. Must the studies or carrels be renewed? $\square$ yes $\square$ no

20. If so, how often? $\square$ Every semester/quarter $\square$ Annually

$\square$ Other (please specify )

21. What is the renewal process? (Please describe briefly)

22. Besides the faculty member, who else can unlock the carrel?

Library staff? $\square$ yes $\square$ no (If yes, please list job titles of library staff members who have access, such as circulation clerks, student workers, etc. )

The faculty member's graduate assistants? $\square$ yes $\square$ no

Others? (Please list job titles)

23. Please indicate the kinds of furniture and equipment provided in the study or carrel.

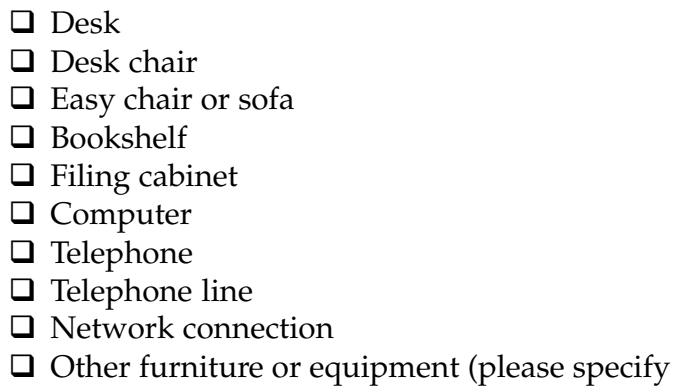
)

Please return your completed survey in the enclosed return envelope. If possible, please attach a copy of your institution's written policy governing the use of faculty carrels or studies. Thank you for your time and help! 


\section{APPENDIX C}

Survey Results

1. Does your library provide individual lockable studies or carrels to faculty members? (If no, skip remaining questions.)

2. How many FTE faculty members does your institution employ?

$\begin{array}{cc}\text { Yes } & \text { No } \\ 47(75 \%) & 16(25 \%)\end{array}$

$\begin{array}{cc}\text { Mean } & \text { Range } \\ 2,002 & 659-7,605 \\ \text { Mean } & \text { Range } \\ 20,642 & 3,000-41,445 \\ & \\ \text { Mean } & \text { Range } \\ 5,771 & 1,740-12,460 \\ & \\ \text { Mean } & \text { Range } \\ 122 & \text { 3-680 }\end{array}$

6. Would you characterize your library's

Study Carrel individual faculty space as a study or a carrel? $17(36 \%)$ $30(64 \%)$ (A carrel is usually considered to be a small lockable space with ust enough room for a desk, attached shelf, and chair. A study is somewhat larger and may have room for additional furnishings.)

7. Are retired faculty members eligible for studies or carrels?

$\begin{array}{cc}\text { Yes } & \text { No } \\ 36(77 \%) & 11(23 \%)\end{array}$

8. Are your studies or carrels fully occupied?

$\begin{array}{cc}\text { Yes } & \text { No } \\ 33(70 \%) & 14(30 \%)\end{array}$

9. Is there a waiting list for studies or carrels?

$\begin{array}{ccc}\text { Yes } & \text { No } & \text { NR } \\ 22(47 \%) & 24(51 \%) & 1(2 \%) \\ \text { Mean } & \text { Range } & \\ 8 & 2-57 & \\ & & \\ \text { Yes } & \text { No } & \text { NR } \\ 25(53 \%) & 19(40 \%) & 3(6 \%) \\ \text { Yes } & \text { No } & \text { NR } \\ 14(30 \%) & 32(68 \%) & 1(2 \%)\end{array}$

10. If so, how many people are typically on the waiting list?

11. Is the number of studies or carrels adequate for the number of faculty at your institution?

12. Can faculty check out books and materials to the study or carrel? (This is not the same as checking out books to him-or herself and leaving them in the carrel. If books are checked out to a carrel, library staff know where they are and can access them if another patron needs them.) 
The Life of the Mind 25

\section{APPENDIX C}

\section{Survey Results (continued)}

13. Please rank the top three disciplines that are represented by your study or carrel holders (indicate using "1," "2," and "3").

Humanities (English, philosophy,

languages, classics, etc.)

Social Sciences (history, psychology, sociology, political science)

Fine Arts

Sciences

Engineering

Business

Education

Health Sciences

Professional Schools (social work, library science, law, journalism, etc.)

Other (please specify)

(No Response)

14. Can you provide an approximate breakdown of the studies' or carrels' occupancy by gender?

15. Is there a written policy that governs the use of the studies or carrels?

16. If so, could you send us a copy of it? (If yes, please attach.)

17. Is there a limit on how long a faculty member can keep a carrel or study?

18. If so, what is the limit?

$$
\begin{array}{cccc}
12 \text { months } & 24 \text { months } & \text { Other } & \text { NR } \\
6(40 \%) & 3(20 \%) & 4(27 \%) & 2(13 \%)
\end{array}
$$

19. Must the studies or carrels be renewed?

$$
\begin{array}{ccc}
\text { Yes } & \text { No } & \text { NR } \\
41(87 \%) & 2(4 \%) & 4(9 \%)
\end{array}
$$

20.If so, how often?

$$
\text { Every semester or quarter Annually Other }
$$$$
17(41 \%) \quad 21(51 \%) \quad 3(7 \%)
$$

21. What is the renewal process?

(Please describe briefly)

22. Besides the faculty member, who else can unlock the carrel?

Library staff? (If yes, please list job titles of library circulation clerks, student workers, etc.

$$
\text { ) }
$$

The faculty member's graduate assistants? Others? (Please list job titles

$\begin{array}{ccc}\text { Yes } & \text { No } & \text { NR } \\ 44(94 \%) & 0(0 \%) & 3(6 \%) \\ 11(23 \%) & 30(64 \%) & 6913 \%) \\ & & \end{array}$


26 College \& Research Libraries

January 2004

APPENDIX C

Survey Results (continued)

23. Please indicate the kinds of furniture and equipment provided in the study or carrel. Desk

Desk chair

Easy chair or sofa

Bookshelf

Filing cabinet

Computer

Telephone

Telephone line

Network connection

Yes No NR

$44(94 \%) \quad 0(0 \%) \quad 3(6 \%)$

$44(94 \%) \quad 0(0 \%) \quad 3(6 \%)$

$1(2 \%) \quad 43(92 \%) \quad 3(6 \%)$

$41(87 \%) \quad 3(6 \%) \quad 3(6 \%)$

$7(15 \%) \quad 37(79 \%) \quad 3(6 \%)$

$0(0 \%) \quad 44(94 \%) \quad 3(6 \%)$

$2(4 \%) \quad 42(89 \%) \quad 3(6 \%)$

$4(9 \%) \quad 40(85 \%) \quad 3(6 \%)$

$24(51 \%) \quad 19(40 \%) \quad 4(9 \%)$

Other furniture or equipment (please specify): Three respondents $(6 \%)$ reported

that their faculty spaces provided wireless internet connections.

$\mathrm{NR}=$ No response 